\title{
メタクリル酸フッ化物-メタクリル酸メチルコポリマーフィルム からのフッ素イオン放出*
}

\author{
増原 英一苂・小島 克則*1 $・$ 門磨 義則*1
}

(受付 1982 年 6 月 8 日・雷查終了 1982 年 11 月 21 日)

\begin{abstract}
要 旨 口腔内において長期間にわたってフッ素イオンを徐々に放出させ，歯のエナメル質をフッ 素化し抗5触性を向上させる材料として,メタクリル酸フッ化物 (MF)-メタクリル酸メチル (MMA) コポリマーを検㶦した。 モ/マー仕込み組成の異なる5 種類の MF-MMA コポリマーをベンゼン溶 液中での共重合により合成した。 MF-MMA コポリマー単独のフィルムあるいはポリメタクリル酸 メチル (PMMA) とのブレンドポリマーからなるフィルムを用いて，これを $0.2 \mathrm{M}$ のリン酸緩衙液 中 (pH 7) に浸漬した場合のフィルムからのフッ素イオン放出速度及び引張強度の程時的変化を調べ た. MF-MMA コポリマーフィルムに比して, ブレンドポリマーフィルムではポリマー中のフッ素 含有率に対するフッ素イオン放出速度は大きく，加水分解に伴って酸無水物が生成していることが IR スペクトルで認められた。更に常温硬化時間に及ぼす MF の影響を検刢したが, MF-MMA コ ポリマーが葴科材料として実用性のあることが認められた。
\end{abstract}

\section{1 緒 謈}

フッ素が菓のら蝕予防に効果があることは古くから知 られており ，含フッ素化合物を利用して様々な方法で 歯に応用されてきた，特に歯のエナィル質の表面にフ， 素化合物の水溶液を鉒布し，短期間表層のエナメル質と 接触させるフッ素局所塗布法は広く行われ，臨床に护け るら蝕予防効果も数多く報告されてきた．上く用いられ るフッ素化合物としては，フッ化ナトリウム2)，フッ化 第一スズ8)，フッ化アンモニウム誘導体 ${ }^{4)}$ などがあげら れる.エナメル質のフッ素化ではヒドロキシアパタイト がフルオロフパタイトになり，耐酸性が増大することが 抗5蝕性発現の一因とされているが，通常この反応は遅 いので短期間のフッ素銼布では一時的にはエナメル質の 表面におけるフッ素イオン濃度は高くなるか，塗布終了 後速やかにフッ素イオンは唾夜中に拡散し溶出してしま

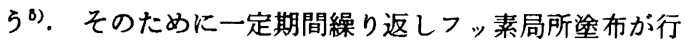
われてきた。

そこで著者らは，崡の表面に長期間接着・保持され， その間徐々にフッ素イオンを放出する歯科用高分子材料 を検討してきた. メタクリル酸フッ化物 (MF) とメタク リル酸メチル(MMA)のコポリマーが水中で徐々に分解 してフッ素イオンを放出し ${ }^{\theta)}$ ，そのフッ素イオン放出速

*本研究を「菌科用フッ素徐放性ポリマーの研究 第 5 報」とする.

*1 東京医科歯科大学医用器材研究所 ( 101 千代田区 神田駿河台 2-3-10)
度が共重合体の一次構造に依存していることを明らかに しだ、。本研究では、メタクリル酸フッ化物とメタクリ ル酸メチルのコポリマー及びポリメタクリル酸メチル (PMMA) とのブレンドポリマーの緩衝溶液中に批りる フッ素イオン放出速度を調べた結果, 興味ある知見が得 られたので報告する.

\section{2 実験方法}

\section{1 メタクリル酸フッ化物}

MF は, $477 \mathrm{~g}$ のメタクリル酸塩化物と $462 \mathrm{~g}$ の三フ ッ化アンチモンを 7 時間環流させてから粗生成物を留去 し ${ }^{8)}$ ，更に中性アルミナ（メルク社）カラムを通してか ら蒸留精製した，収率 $48.2 \%$ ， bp $56.5 \sim 57.5^{\circ} \mathrm{C}$. IR スペクトル： $\mathrm{C}=\mathrm{O} 1,805 \mathrm{~cm}^{-1} ; \mathrm{C}=\mathrm{C} 1,640 \mathrm{~cm}^{-1}$, NMR スペクトル $\left(\mathrm{CDCl}_{3}\right): \alpha-\mathrm{CH}_{3} \delta=2.00 \mathrm{ppm} ;=$ 重結合のプロトン $\delta=5.93,6.26 \mathrm{ppm}$.

\section{2 試菜}

重合溶媒のペンゼンは濃硫酸で洗浄の後に, 水洗・乾 燥し，金属ナトリウム存在下で蒸留して精製した．重合

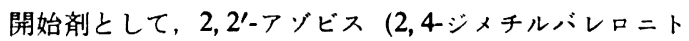
リル）(V-65，和光純薬工業(株)製）を用いた. MMA は常法に従って精製した. 塩化×チレンは水及び炭酸ナ トリゥム水溶液で洗浄した後に, 塩化カルシウムで乾燥 して蒸留したものを用いた.

\section{3 重合方法}

MF と MMA の共重合はペンゼン溶液中で行った. 重合用ガラス封管中に所定量の MF と MMA を秤取 
増原・小鼠・門磨

Table 1. Copolymerization of MF with $\mathrm{MMA}^{\mathrm{a})}$

\begin{tabular}{crccccc}
\hline & \multicolumn{2}{c}{ Weight of monomers } & & \multicolumn{2}{c}{$\begin{array}{c}\text { Mole fraction } \\
\text { Copolymer }\end{array}$} & \multicolumn{2}{c}{$\mathrm{g})$} & $\begin{array}{c}\text { Benzene } \\
(\mathrm{g})\end{array}$ & $\begin{array}{c}\text { Yield } \\
(\%)\end{array}$ \\
\cline { 2 - 3 } & MF & MMA & & & \\
\hline PMF-2 & 4.00 & 18.17 & 0.200 & 22.17 & 79.3 \\
PMF-4 & 9.00 & 15.32 & 0.400 & 24.32 & 90.0 \\
PMF-6 & 14.00 & 10.60 & 0.600 & 24.60 & 83.6 \\
PMF-7 & 17.00 & 8.27 & 0.700 & 25.27 & 47.9 \\
PMF-8 & 20.00 & 5.68 & 0.800 & 25.68 & 27.3 \\
\hline
\end{tabular}

a) Polymerization conditions: initiator $0.5 \mathrm{wt} \%$ of total monomer; temperature $50^{\circ} \mathrm{C}$ for $16 \mathrm{~h}, 55^{\circ} \mathrm{C}$ for $1 \mathrm{~h}, 60^{\circ} \mathrm{C}$ for $23 \mathrm{~h}$.

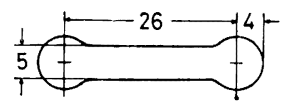

Fig. 1. Dimension of a film specimen $(\mathrm{mm})$.

し，重合開始剤の V-65をモノマーに対して $0.5 \mathrm{wt} \%$ 添加し, 重合溶媒のペンゼンをモノマー総濃度が 50 wt％となるように加えた，窒素で十分に空気を固換し た後に，ガラス封管を溶封し， $50^{\circ} \mathrm{C}$ で 16 時間， $55^{\circ} \mathrm{C}$ で 1 時間, 更に $60^{\circ} \mathrm{C}$ で 23 時間恒温水槽中で静置して 重合させた. 重合終了後反応混合物を塩化メチレンで適 度な粘度になるように希䣋してから，大量のエーテル中 に注いでコポリマーを沈殿させ, 沪別してから減圧下に 乾燥した。

\section{4 フィルムの作製}

MF-MMA コポリマーあるいは PMMA とのブレン ドポリマーフィルムは塩化メチレン溶液からガラス板上 にキャストして得た．膜厚は $0.035 \sim 0.050 \mathrm{~mm}$ であっ た. このフィルムを Fig. 1 に示すダンベル型に切り抜 いて試験片とした，各サンプルフィルム 5 枚を 1 組とし て $20 \mathrm{ml}$ の $0.2 \mathrm{M}$ リン酸緩衝夜 (pH 7) 中に浸漬し $37^{\circ} \mathrm{C}$ にて所定の期間反応させた．13，31，60 日後サン プルフィルムを取り出し，ただちに各フィルムの引張強 度を測定し，またりン酸緩衝液中に溶出したフッ素イオ ン濃度を测定した。

\section{5 フッ素イオン濃度の測定}

フッ素イオン濃度はフッ素イオン電極（米国オリオン 社製 96-09型）をマイクロプロセッサーイオンアナライ ザー（米国オリオン社製 901 型）に接続して測定した. イオン強度調整用髣衝溶液 (TISAB) は, $57 \mathrm{ml}$ の水酢 酸, $58 \mathrm{~g}$ の塩化ナトリウム, $0.30 \mathrm{~g}$ のクエン酸ナトリ ウムに水酸化ナトリウムを加えて pH 5.5 に調節し, 全量を $1 l$ にしたものを用いだ．サンプル溶液に TISAB を 40\% になるように添加し, あらかじめ求め ておいた検量線からフッ素イオン濃度を決定した。
Table 2. Copolymer composition, numberaverage molecular weight and glass transition temperature of MF-MMA copolymer

\begin{tabular}{cccc}
\hline \hline Copolymer & $\begin{array}{c}\text { Mole fraction } \\
\text { of MF in } \\
\text { copolymer })\end{array}$ & $\begin{array}{c}M_{n} \\
\left(\times 10^{4}\right)\end{array}$ & $\begin{array}{c}T_{\mathrm{g}} \\
\left({ }^{\circ} \mathrm{C}\right)\end{array}$ \\
\hline PMF-2 & 0.224 & 23 & 125 \\
PMF-4 & 0.418 & 7.4 & 133 \\
PMF-6 & 0.549 & 5.7 & 134 \\
PMF-7 & 0.672 & 5.7 & 137 \\
PMF-8 & 0.716 & 2.5 & 143 \\
\hline
\end{tabular}

a) Determined by infrared spectroscopy and fluorine analysis.

\section{6 硬化時間の測定}

MF-MMA コポリマーを含有する歯科用レシンンの硬 化時間は ISO 規格試案に基ついて測定した. 常温重合 触媒 (トリ-n-プチルホウ素酸化物, TBBO) $(0.019 \mathrm{~g})$ を液成分 $(0.240 \mathrm{~g})$ に加えてからポリマー粉末 $(0.200$ g) と 30 秒間練和後, 内径 $4 \mathrm{~mm}$, 潹さ $6 \mathrm{~mm}$ の型に 填入し, 中心部に熱電対を挿入して温度を測定し, 温度 が最大となる時間を硬化時間とした。

\section{7 装置及ひ物性測定}

MF-MMA コポリマーの組成はフッ素分析及び IR スペクトルから決定した. IR スペクトルはコポリマー を塩化メチレンに溶解させ，KRS-5 液体気密セルを用 いて (株) 日立製作所製赤外分光光度計（日立 285 型）で 測定した. ポリマーフィルムの引張強度は新興通信工 業 (株) 製張力計を用い, 引張速度 $5 \mathrm{~mm} / \mathrm{min}$ で室温に て測定した. MF-MMA コポリマーの DSC 測定は理 学電機(株)製示差走查熱量天秤を用いて, 試料約 $10 \mathrm{mg}$, 昇温速度 $5^{\circ} \mathrm{C} / \mathrm{min}$ で空素気流下にて行った。

\section{3 結果及ひ考察}

\subsection{MF-MMA コポリマーの合成}

MF と MMA の共重合をベンゼン中で行った場合に 
Table 3. Composition of blended polymer films

\begin{tabular}{lcccc}
\hline \hline & $\begin{array}{c}\text { Weight of MF-MMA } \\
\text { copolymer }(\mathrm{g})\end{array}$ & $\begin{array}{c}\text { Weight of PMMA } \\
(\mathrm{g})\end{array}$ & $\begin{array}{c}\text { Mole fraction of } \\
\text { MF unit in film }\end{array}$ & $\begin{array}{c}\text { Fluoride content } \\
\text { in film }(\%)\end{array}$ \\
\hline PMF-2 & - & - & 0.224 & 4.4 \\
PMF-4 & - & - & 0.418 & 8.4 \\
PMF-6 & - & - & 0.549 & 11.2 \\
PMF-7 & - & - & 0.672 & 13.9 \\
PMF-2B & 0.4915 (PMF-2) & 0.5085 & 0.112 & 2.2 \\
PMF-4B & 0.4016 (PMF-4) & 0.5984 & 0.173 & 3.4 \\
PMF-6B & 0.5861 (PMF-6) & 0.4059 & 0.333 & 6.6 \\
PMF-7B & 0.6083 (PMF-7) & 0.3917 & 0.422 & 8.4 \\
\hline
\end{tabular}

は，重合温度を $60^{\circ} \mathrm{C}$ 以上で始めると最終的には橋かけ したコポリマーを与えるので，重合開始剤として V-65

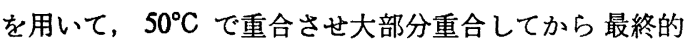
に $60^{\circ} \mathrm{C}$ に昇温した．仕込みモノマー組成を変えた共重 合の結果を Table 1 亿示す. 仕込み中の MF の割合が 0.7 を越えると重合収率の低下が顕著になった．これは MF の分解に伴う HF の発生が原因であり, 重合を収 率良く行らためにはできるだけ低温で重合を行らのが望 ましい，本研究では実用性を考え，重合収率を高くした ので得られたコポリマーの組成は重合初期と高重合率の 後期で異なり，大きな分布を有している. MF-MMA コポリマーの MF 部分の加水分解は一次構造に依存す るので7)、コポリマー中の MF の平均含有率が同一で る，共重合を低重合率に抑之た場合に得られる比較的均 一な組成のコポリマーと比べで，，組成の分布が大きな ポリマーからのフッ素イオンの放出挙動はかなり異なる と考えられる. Table 2 に MF-MMA コポリーーの 平均組成, 数平均分子量及びガラス転移温度を示与. ポリマー中の MF の平均含有率は仕込み中の MF の割 合が大きくなるにつれて，增大しているが，一方では分 子量が低下し，PMF-8 では $2.5 \times 10^{4}$ であった．ガラ ス転移温度はポリメタクリル酸フッ化物 (PMF) の方が PMMA より高いので，MF の含有率とともに 125 か ら $143^{\circ} \mathrm{C}$ に增大した。

MF-MMA コポリマー単独あるいは PMMA（分子 量: $\left.M_{n}=1.9 \times 10^{5}\right)$ とのプレンドポリマーを塩化メチレ ン溶夜からガラス板上にキャストしてフィルム状の試料 を得た. Table 3 に使用したポリマーフィルム中の MF の割合及びフッ素含有率を示す. PMF-8 は MF の含有 率が最も大きいが，分子量が小さいために強しんなフ、 ルムは得られなかった．他のコポリマー及びブレンド リマーからは透明なフィルムが得られた。

\section{2 ポリマーフィルムからのフッ素イオンの放出速} 度

口腔内で歯牙のフッ素化に必要なフッ素イオン量はご くわずかであるか，式 (1) に示すフルオロアパタイトの

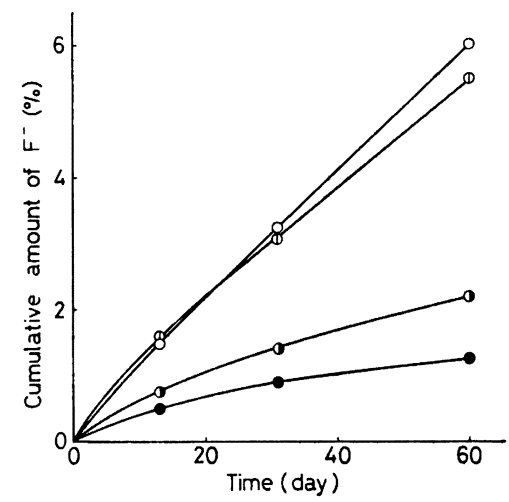

Fig. 2. Effect of the MF content on the release rate of fluoride ions from MF-MMA copolymer films: PMF-6; O, PMF-7.

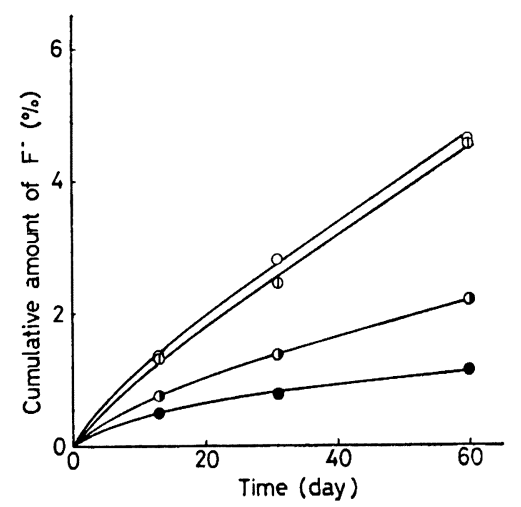

Fig. 3. Release rate of fluoride ions from blended copolymer films: - PMF-2B; PMF-4B; (D, PMF-6B; O, PMF-7B.

生成は遅い反応であるので，かなりの長期間にわたって フッ素イオンを供給していくことが望しい。 
增原・小島・門磿

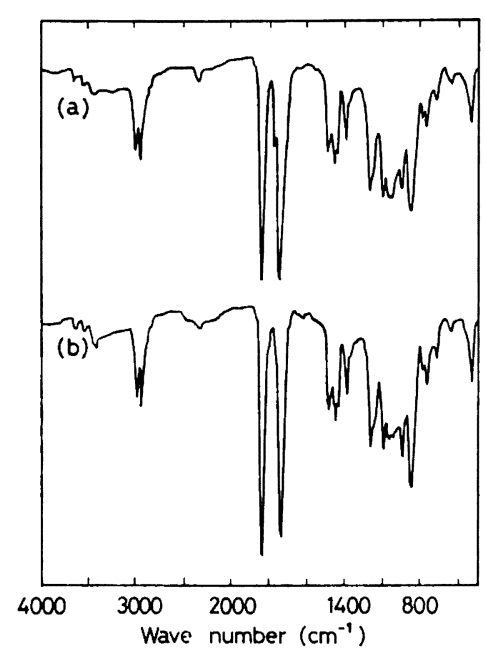

Fig. 4. IR spectra of PMF-6 before (b) and after 60 days of the immersion in water at $60^{\circ} \mathrm{C}$ (a).

$$
\mathrm{Ca}_{10}\left(\mathrm{PO}_{4}\right)_{8}(\mathrm{OH})_{2}+2 \mathrm{~F}^{-} \rightarrow \mathrm{Ca}_{10}\left(\mathrm{PO}_{4}\right)_{8} \mathrm{~F}_{2}+2 \mathrm{OH}^{-}
$$

ここでは歯のエナィル質表面上に MF-MMA コポリマ 一を含有したレジンを塗布し硬化させ、このフィルム状 硬化物から徐々に放出されたフッ素イオンがエナィル質 中に浸透しフルオロアパタイトを形成して歯牙を強化す る材料の開発を目的としている. 歯科用レシンは粉と夜 の成分から構成され ${ }^{10)}$ ，粉成分に MF-MMA コポリマ 一そのものを用いるか, その他のポリマーと混合して 用い, 液成分として MMA が使用される. 硬化物から のフッ素イオンの放出挙動は MF-MMA コポリマーそ のものとはかなり異なることが考えられるので, MFMMA コポリマーと PMMA のブレンドポリマーをそ のモデルとして用いた.

Fig. 2 及び 3 に pH 7 のリン酸緩衝液中での酸フッ 化物の加水分解によるフッ素イオンの放出量（フィルム 中のフッ素含有量に対する放出されたフッ素量の百分 率) の経時的変化を示す.フッ素イオンの放出速度は経 時的に若干低下しており 60 日間浸漬後の平均フッ素イ オン放出速度は, 0.095 (PMF-7), 0.082 (PMF-6), 0.027 (PMF-4), 0.011\%/day (PMF-2) であった. 一 方ブレンドポリマーの場合には, 0.072 (PMF-7B), 0.068 (PMF-6B), 0.027 (PMF-4B), 0.010\%/day (PMF2B) のフッ素イオン放出速度であった. PMF-6 のフィ ルムを $60^{\circ} \mathrm{C}$ の蒸留水中に 2 カ月間浸漬したときの IR スペクトルの変化を Fig. 4 に示す. エステルと酸フッ 化物に基つくく吸収がそれぞれ，1,735, 1,829 $\mathrm{cm}^{-1}$ に観 察され，酸フッ化物の加水分解に伴い, 酸フッ化物によ
る吸収強度が小さくなり，1,765 $\mathrm{cm}^{-1}$ に新しいピーク が現れている. ジオキサンー水を溶媒とした均一系での MF-MMA コポリマーの加水分解は，初期の段階では もっぱら式 (2) の反応で酸無水物が形成されることが示 された7).

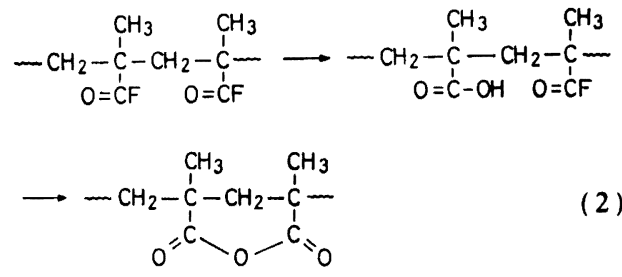

酸無水物 6 員環は $1,765 \mathrm{~cm}^{-1}$ に特性吸収を有するの で11)，MF-MMA コポリマーのフィルム状態での加水 分解でも酸無水物が形成されると考えられる. さらに加 水分解が進行するとしだいにカルボン酸に基づく吸収も 影著になった.

均一系の加水分解で示されたように，初期の段階では MF-MF 連鎖で加水分解が起こるので, フッ素イオン の放出速度はコポリマー中の MF の含有量だけでなく MF-MF 連鎖の確率に依存している. したがって MFMMA フィルムとブレンドポリマーフィルムを比較し てみるとブレンドポリマーは PMMA で希䣋されて MF-MMA コポリマー含有率が低下しているが，フッ 素イオン放出速度は PMF-2B と PMF-4B では元のコ ポリマーとほほ同じで, PMF-6B と PMF-7B ではやや 低下しているだけである，例えば PMF-7B と PMF-4 は, 大体同程度のフッ素含有率であるがフッ素イオンの 放出速度は PMF-7B の方がはるかに大きい.これは PMF-7B は PMF-7 と PMMA の混合物であるのでフ ^ルム中の MF-MF 連鎖の確率が PMF-4に比して大 きいことも一因である.このように MF-MMA コポリ マーを含有するフッ素イオン徐放性材料は, ポリマーの 構造を変化させることでフッ素イオンの放出速度の調節 が可能であると考えられる.

\subsection{MF-MMA コポリマーの引張強度}

MF-MMA コポリマーを含有する 歯科用レジンがロ 腔環境下に長期間さらされることを考えると加水分解に よる機械的強度の低下が問題となってくる. そこで各ポ リマーフィルムを Fig. 1 に示寸形状に切り拔き, pH 7 のリン酸緩衝夜中に所定期間浸漬した場合の引張強度の 変化を調べた. 5 枚のフィルム状試料を一組として張力 計で引張強度を测定した結果を Table 4 に示す. 使用 した PMMA の分子量は $M_{n}=1.9 \times 10^{5}$ であり, 引張 強度はかなりのバラッキがあるものの全般的にみて, 分 子量に依存している. MF の含有量の少ないコポリマー は60日間の浸漬で, 強度はほぼ一定かやや低下する傾 向を示したが, PMF-6 や PMF-7 の場合は少し複雑で, 
Table 4. Change in tensile strength of polymer films after immersion in a phosphate buffer of $\mathrm{pH} 7$ at $37^{\circ} \mathrm{C}^{\mathrm{a}} \mathrm{C}$

\begin{tabular}{lcccc}
\hline \hline \multirow{2}{*}{ Film } & \multicolumn{4}{c}{ Tensile strength after immersion $(\mathrm{MPa})$} \\
\cline { 2 - 5 } & 0 & 13 days & 31 days & 60 days \\
\hline PMMA & $46.1(1.8)$ & $44.7(4.1)$ & $46.6(2.1)$ & $36.1(5.9)$ \\
PMF-2 & $50.5(5.1)$ & $42.9(5.4)$ & $43.0(3.1)$ & $41.3(6.5)$ \\
PMF-4 & $39.4(3.6)$ & $37.1(11.4)$ & $34.4(1.9)$ & $32.1(4.7)$ \\
PMF-6 & $24.6(6.1)$ & $20.8(5.0)$ & $17.6(2.7)$ & $25.1(3.9)$ \\
PMF-7 & $23.6(8.4)$ & $17.8(4.9)$ & $19.1(1.3)$ & $25.5(6.1)$ \\
PMF-2B & $40.2(4.9)$ & $34.2(2.9)$ & $40.2(5.5)$ & $39.1(4.6)$ \\
PMF-4B & $28.6(4.4)$ & $26.0(7.4)$ & $27.3(4.6)$ & $37.2(4.2)$ \\
PMF-6B & $20.6(5.5)$ & $22.7(5.0)$ & $23.7(5.5)$ & $27.5(7.7)$ \\
PMF-7B & $25.2(7.8)$ & $21.0(4.6)$ & $20.9(7.9)$ & $30.1(6.6)$ \\
\hline
\end{tabular}

a) Numbers in parentheses are standard deviations.

必ずしも単調に強度の低下が起こらず，60日間浸漬後 は元の值に回復している. 加水分解の初期の段階で酸無 水物の形成か：IR スペクトルから確認されており,フィ ルムの場合には分子内だけでなく分子間の酸無水物形成 による橋かけの結果強度が增大寸ることも考えられるの で，更に詳細に検討する必要があると思われる．MFの 含有率の高いMF-MMA コポリマーは引張強度が小さ く，PMMA と混合することにより強度の增大が期待さ れたが，顕著な傾向は認められなかった。

\section{4 常温重合硬化に及ほす MF-MMA コポリマー の影䅧}

MF と MMA のベンゼン中の共重合において，仕込 みモノマー中の MF の割合が大きくなるに従って重合 収率や分子量が低下することから明らかなよらに酸フッ 化物はラジカル重合を阻害する傾向がある。そこで MF-MMA コポリマーを含有する 歯科用レジンを試作 し，重合硬化に要する時間を測定した．MF-MMA コ ポリマーの中で, MF 含有量が適当で重合収率の良好な PMF-4 と PMF-6 を使用した. このレジンは粉成分, 液成分と開始剤である TBBO からなっており ${ }^{12)}$, 液成 分として MMA を用い, 粉成分中の PMMA と MFMMA コポリマーの比率が重合硬化時間に及ぼす影響

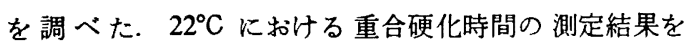
Fig. 5 に示す. いずれの MF-MMA コポリマーの場合 にも粉成分中の MF-MMA コポリマー含有率が 50 $\mathrm{wt} \%$ 以下では重合硬化時間はほぼ一定であったが，50 wt％を越えると重合速度はしたいに低下した， 口腔内 では体温, $37^{\circ} \mathrm{C}$, で重合が進行するので, 実際は硬化に 要する時間はさらに短いと考えられるが，操作性などを 考虑すると粉成分中の PMF-4 あるいは PMF-6 の割合 は $50 \mathrm{wt} \%$ 以下で使用するのが好ましいと思われる。

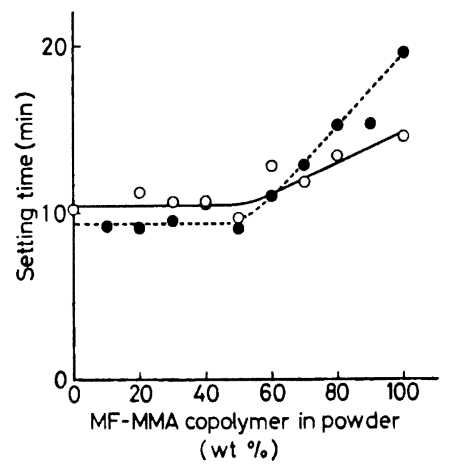

Fig. 5. Effect of the MF-MMA copolymer content in powder on the setting time of the experimental resin: -O-, PMF-4; --- --- , PMF-6.

\section{4 結 䛺}

1) MF と MMA のベンゼン中での共重合を $60^{\circ} \mathrm{C}$ 以上で行らと橋かけが著しくなるので， $50^{\circ} \mathrm{C} て ゙$ 重合を 始め最終的に $60^{\circ} \mathrm{C}$ まで昇温して MF-MMA コポリマ 一を得た。仕込みモノマー中の MF の割合が大きくな るにつれて生成コポリマーの分子量が低下し，仕込みモ ノマー中の MF のモル分率が 0.7 を越えると重合収率 も低くなった.

2) MF-MMA コポリマーフィルムを $\mathrm{pH} 7$ のリン 酸緩衝夜中に浸漬した場合のフィルムからのフッ妻イオ ン放出速度はコポリマー中の MF の含有率とともに增 大したが, MF-MMA コポリマーを PMMA とブレン ドしてもフッ素イオン放出速度はそれほど低下せず，フ ッ素イオン放出速度はフィルム中の MF の含有率だけ でなく、MF-MF 連鎖の確率にも依存した。このこと から MF の含有率を一定に保ちつつ, フッ素イオンの 放出速度を調節できると考えられる。

3) MF-MMA コポリマーフィルムの引張強度は, コポリマー中の MF の割合が大きくなるにつれて低下 し，これは主として分子量の低下に基つくと思われる. リン酸楥衝溶液中に浸漬した後, 強度が回復する傾向か ら，MF 含有率の高いフィルム中での分子間の酸無水物 の形成が示唆された.

4) 歯科用レジンの粉成分として PMF-4 あるいは PMF-6 と PMMA の混合物を使用すると， PMF-4 あ るいはPMF-6 の揢合が 50 wt\% 以下であれば，MMA の重合硬化時間に及ぼす MF の影響は無視でき，歯科 用フッ素徐放性材料としての実用性が期待できる.

$$
\text { 文献 }
$$

1) H. J. Sanders, Chem. Eng. News, Feb. 25, 30 (1980). 
2) J.W. Stamm, J. Canad. Dent. Assn., 40, 501 (1974).

3) L.G. Petersson, Odont. Revy, 27, 25 (1976).

4) V. Caslavska, E.C. Moreno, and F. Brudevold, Archs. Oral Biol., 20, 333 (1975).

5) H. Lee, D.E. Ocumpaugh, and M.L. Swartz, J. Dent. Res., 51, 183 (1972).

6) Y. Kadoma, E. Masuhara, Y. Imai, and M. Ueda, Makromol. Chem. 182, 273 (1981).

7) Y. Kadoma, E. Masuhara, and J.M. Anderson, Macromolecules, 15, 1119 (1982).
8) B. W. Howk and R. A. Jacobson, Chem. Abstr., 42, 4794d (1948).

9) J.W. Ross, Anal. Chem., 40, 1169 (1968).

10) E. Masuhara and I. Ohmori, Quintessence International, 8, 75 (1977).

11) 桜田一郎, 岩垣武久, 坂口康義, 高分子化学, 21, 270 (1964).

12) N. Nakabayashi, E. Masuhara, E. Mochida, and I. Ohmori, J. Biomed. Mater. Res., 12, 149 (1978).

\section{Release of Fluoride Ions from Methacryloyl Fluoride-Methyl Methacrylate Copolymer Film*}

Eiichi Masuhara ${ }^{* 1}$, Katsunori KoJIMA ${ }^{* 1}$, and Yoshinori Kadoma*1

*Studies on Dental Fluoride-Releasing Polymers. V.

*1 Institute for Medical and Dental Engineering, Tokyo Medical and Dental University (3-10, Kanda-surugadai 2-chome, Chiyoda-ku, Tokyo 101, Japan)

Methacryloyl fluoride (MF)-methyl methacrylate (MMA) copolymers with different copolymer compositions were synthesized to develop a new dental material which released fluoride ion for a prolonged period of time in the oral environment and increased the resistance of tooth to decay. Films used for the measurements of the release rate of fluoride ion and tensile strength were prepared from both the pure MF-MMA copolymers and the polymers blended with poly (methyl methacrylate) (PMMA). The fluoride ion releasing rate of the MF-MMA copolymer blended with PMMA was higher in $0.2 \mathrm{M}$ phosphate buffer solution of $\mathrm{pH} 7$ than that of the pure MF-MMA copolymer at the same fluoride content and infrared spectroscopy revealed anhydride formation during hydrolysis. The effect of MF units in the copolymers on the setting time of the experimental dental resin was also determined and the usefulness of the MF-MMA copolymer as fluoride-releasing material was discussed.

KEY WORDS Methacryloyl Fluoride / Methyl Methacrylate / Copolymer / Release of Fluoride Ion / Tensile Strength / Setting Time /

(Received June 8, 1982: Accepted November 21, 1982)

[Kobunshi Ronbunshu, 40 (3), 151-156 (1983)] 